\title{
Elemental Study of Bangladeshi Fish Samples Using PIGE Technique
}

\author{
S. M. Fahad,
}

Department of Physics, Jahangirnagar University, Savar, Dhaka, Bangladesh.

Md. Joynal Abedin, Accelerator Facilities Laboratory, Atomic Energy Center, Dhaka, Bangladesh.

Md. Obaidur Rahman, Md. Abdullah Al Rony, F. A. Sabbir Ahamed,

Department of Physics, Jahangirnagar University, Savar, Dhaka, Bangladesh.

M. Ajijul Hoq,

Institute of Energy Science, Atomic Energy Research Establishment,

Savar, Dhaka, Bangladesh.

Doi: 10.19044/esj.2018.v14n18p371 URL:http://dx.doi.org/10.19044/esj.2018.v14n18p371

\begin{abstract}
Proton induced gamma emission (PIGE) method has been developed at the Accelerator Laboratory of Atomic Energy Center, Dhaka (AECD) for the investigation of various human health related specimens. In the present study PIGE analytical technique has been used for the determination of numerous trace elements in some commonly used fish samples which were collected from Islampur area at Savar. During the experimental work the $\gamma$ rays emitted from the prepared fish samples were measured using a Highpurity Germenium (HPGe) detector. The detected 18 elements were Iron, Calcium, Sodium, Magnesium, Aluminum, Potassium, Vanadium, Chromium, Manganese, Copper, Zinc, Selenium, Bromine, Rubidium, Strontium, Cadmium, Iodine, Lead etc. The objective of this study was to measure the concentrations of these trace elements in the collected fish samples and to investigate whether their concentrations are harmful for human health by comparison with limits set by WHO/FAO. The results obtained indicate that $\mathrm{Fe}, \mathrm{K}$ and $\mathrm{Ca}$ concentrations were relatively high in all samples as compared with the other elements. The measured elemental concentration of $\mathrm{Fe}, \mathrm{Mn}, \mathrm{Zn}, \mathrm{Cu}, \mathrm{Cr}$ and $\mathrm{V}$ in all fish samples were found to be above the $\mathrm{WHO} / \mathrm{FAO}$ recommended limits.
\end{abstract}


Keywords: Analytical method; Proton induced gamma emission )PIGE(; Trace Elements; Fish samples and Elemental concentration

\section{Introduction}

Fish is regarded as a potentially cheap source of protein of special significance to developing countries like Bangladesh where problems of nutritional deficiencies persist. Keeping in mind that people's everyday demand of nutritious foodstuff like fish it is important to ensure adequate amount of essential elements are present and the toxic elements are at very low concentration in these fish samples. The present study deals with the elemental analysis of various fish samples using Proton Induced Gamma Emission )PIGE( method. Worldwide a number of sensitive and accurate analytical methods are used for the determination of elemental concentration of various human health related specimens. Nuclear analytical techniques have been applied to irradiate the samples and MAESTRO-32 software has been used for data analysis to study the elemental profile of fish samples at the Accelerator Laboratory of Atomic Energy Centre, Dhaka.

Proton induced gamma emission (PIGE) is a multi-elemental analytical method based upon gamma-ray spectrometry in energy dispersive mode which is essentially important for the determination of light elements present in small quantities in most medical, environmental and biological samples. PIGE is a multi-elemental analytical technique which is suitable for non-destructive elemental analysis used especially for low mass elements. PIGE analysis is based on the detection of prompt gamma rays emitted from the excited nuclei following the reactions $(\mathrm{p}, \gamma),(\mathrm{p}, \mathrm{p}, \gamma)$ and $(\mathrm{p}, \mathrm{n}, \gamma) \underline{\text { (Tesmer }}$ and Nastasi, 1995; Deconninck, 1978). The energy of the gamma ray indicates the identity of the isotope and its intensity gives a measure of its concentration in the sample. PIGE method has the advantage of being isotopic in nature with virtually no interference and its sensitivity is high. PIGE was developed using proton beam from the $3 \mathrm{MeV}$ Van de Graaff Accelerator at the Atomic Energy Center, Dhaka (Fazlul Hoque, 2000; Fazlul Hoque et al., 2002a; Fazlul Hoque et al., 2002b).

Trace elements like Fe, Cu, Zn, Co, Mn, Ni, Mo, Se, Cr, I, F, Sm, Si, $\mathrm{V}$ and As are constituents of metabolic enzymes and execute vital metabolic functions. These elements may be an integral part of the enzyme-protein molecule or they may be activators of the enzyme. For developing countries like Bangladesh, the possibility of occurrence of contamination in air, water supply, food with trace elements, arising from agricultural and industrial wastages, and from increasing motorization and urbanization in rural areas may have deleterious effects on the long term health and welfare of the whole population of the country. It is therefore important to investigate the baseline 
data, nature and the extent of the current and potential deficiencies and the toxicity of food articles and their sources (Burton et al., 1953; Underwood, 1977; Water quality Criteria, 1972; National research council committee on food protection, 1972; Ministry of agriculture fisheries and food, 1978; Allaway, 1965).

\section{Brief Description of $3 \mathrm{MeV}$ Van de Graff Accelerator}

This research was performed using the $3 \mathrm{MeV}$ Van de Graff Accelerator at the Atomic Energy Center, Dhaka (AECD) (Fazlul Hoque, 2000). A Van de Graff accelerator was installed in 1964. This generator is a horizontal type accelerator (KN3000). A proton beam of energy up to $3 \mathrm{MeV}$ is obtained from this accelerator manufactured by the high voltage Engineering_Corporation of Burlington, Mass., USA. Hydrogen, Helium and Deuterium are used as source gas to produce proton, deuteron and alpha particle beam current in the range of hundred microamperes at energy up to 3 $\mathrm{MeV}$. The stability of the ion beam is $2 \mathrm{keV}$ at $3 \mathrm{MeV}$. It is also capable of producing neutron or X-ray beams using suitable targets. A 4 nano-second pulsing system was incorporated with the accelerator in 1978. Fig. 1 shows the basic structure of the accelerator facility.

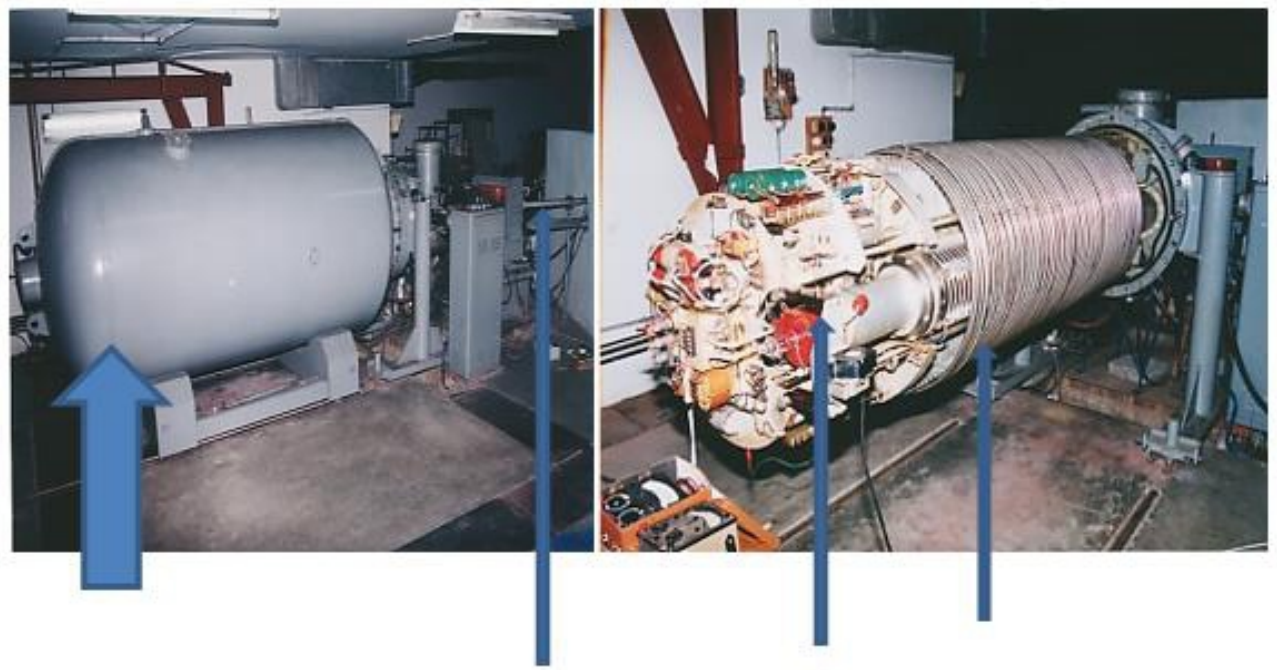

Tank

Switching magnet Electronics Accelerator Tube

Tank Switching magnet Electronics Accelerator Tube

Fig. 1: Photographs of the $3 \mathrm{MeV}$ Van de Graff Accelerator.

\section{Experimental}

\section{Sample Preparation}

Different kinds of fish samples were collected from Islampur area at Savar, a sub-district of Bangladesh. Table-1 lists the scientific name and family name of the fish samples selected in the present study. Samples were 
dried in a Memmert Schutzart DIN 40050 - IP 20 oven at $130{ }^{\circ} \mathrm{C}$ for about 4 to 10 hours to make the samples water free. During the experimental work only the flesh of the fish samples were taken for data analysis. After cooling the samples to room temperature, their weights were taken. The process of heating, cooling and weighing were repeated until a constant weight was obtained to prepare samples that were free of water. The samples were divided into small parts with nose pliers which were cleaned with acetone $\left(\mathrm{CH}_{3}-\mathrm{CO}\right.$ $\mathrm{CH}_{3}$ ). Then the pieces were ground with an agate pestle and mortar into fine powder. In order to avoid contamination after grinding each sample, the pestle and mortar as well as the pliers were cleaned with acetone $\left(\mathrm{CH}_{3}-\mathrm{CO}-\mathrm{CH}_{3}\right)$. These samples were pelletized using Hydraulic pressure, dried and compressed in a holder. Pellets were $10 \mathrm{~mm}$ in diameters and $1 \mathrm{~mm}$ in thickness for analysis by PIGE technique.

Table-1: List of the fish samples studied for elemental concentration analysis.

\begin{tabular}{|c|c|c|c|}
\hline $\begin{array}{c}\text { Serial } \\
\text { No. }\end{array}$ & Local Name & Scientific Name & Family Name \\
\hline 01. & Pangash & Pangasius pangasius & Pangasiidae \\
\hline 02. & Rui & Labeo rohita & Cyprinidae \\
\hline 03. & Taki & Channa punctata & Channidae \\
\hline 04. & Baim & Mastacembelus armatus & Mastacembelidae \\
\hline 05. & Tilapia & Oreochromis mossambicus & Cichlidae \\
\hline 06. & Koi & Anabas testudineus & Anabantidae \\
\hline
\end{tabular}

\section{Irradiation and Data Acquisition}

For the investigation of fish samples IAEA-407 (fish) was used as standard sample. The prepared samples in the form of pellets were exposed to a proton beam of $2.3 \mathrm{MeV}$ using $3 \mathrm{MeV}$ Van de Graff Accelerator at AECD. During the irradiation, the beam current was $20 \mu \mathrm{C}$. The $\gamma$-rays emitted from the prepared samples were measured using a HPGe detector. All experiments were done in the vacuum chamber. Vacuum in the range of the order of $2.0 \times$ $10^{-5}$ mbar was achieved in the chamber. The turbo pumping system was used to evacuate the accelerator tube and rest of the beam line. HPGe detector was connected to a multichannel analyzer (MCA) in order to convert analogue data into digital. $170 \mu \mathrm{m}$ thick Mylar absorber was used in front of the $\gamma$-rays detector for two reasons. Firstly, to save the $\gamma$-rays detector from radiation damage from the scattered high energy particles from the sample and secondly to decrease the count rate in the $\gamma$-ray detector in order to avoid pulse pile up and dead time in the data-acquisition system. Accurate charge measurement was essential for complete quantification of elemental concentrations of a sample. An electron flood gun was used in all experiments in order to prevent charge build up in the samples. Charge measurement was done in the Faraday cup which was positioned at the end of the beam line after the chamber. 


\section{Data Analysis}

Concentrations of different elements were measured by different gamma-ray peak areas produced from PIGE reactions. The reactions were chosen on the basis of detector efficiency, the reaction cross section and the background at the available proton energies. In the case of PIGE each element has the possibility of undergoing a number of different nuclear reactions. However only the reactions which lead to highest yields of gamma rays, were considered. For instance, in the case of $\mathrm{Na},{ }^{23} \mathrm{Na}\left(\mathrm{p}, \mathrm{p}^{\prime}, \gamma\right){ }^{24} \mathrm{Na}$ reaction producing $440 \mathrm{keV}$ gamma-ray was chosen as it produced the most intense gamma-line.

Similarly the ${ }^{19} \mathrm{~F}\left(\mathrm{p}, \mathrm{p}^{\prime}, \gamma\right){ }^{19} \mathrm{~F}$ reaction producing gamma ray energy of $110 \mathrm{keV}$ for ${ }^{19} \mathrm{~F}$, the ${ }^{19} \mathrm{~F}\left(\mathrm{p}, \mathrm{p}^{\prime}, \gamma\right){ }^{19} \mathrm{~F}$ reaction producing gamma ray energy of $197 \mathrm{keV}$ for ${ }^{19} \mathrm{~F}$, the ${ }^{24} \mathrm{Mg}\left(\mathrm{p}, \mathrm{p}^{\prime}, \gamma\right){ }^{24} \mathrm{Mg}$ reaction producing gamma ray peak at $1369 \mathrm{keV}$ for ${ }^{24} \mathrm{Mg}$, the ${ }^{28} \mathrm{Si}\left(\mathrm{p}, \mathrm{p}^{\prime}, \gamma\right){ }^{28} \mathrm{Si}$ reaction producing gamma ray peak at $1779 \mathrm{keV}$ for ${ }^{28} \mathrm{Si}$ were used.

\section{Measurement of Concentrations}

In this experiment the computer code MAESTRO was used for unfolding the spectra. For background removal, the blank spectra were subtracted from each of the elemental spectra. Then identifying elements in the spectrum we found the net area/yield of that peak with the help of MAESTRO software. The spectral data were normalized with charge. Putting the values of $\mathbf{C}_{\text {st }}$ the concentration of the standard sample, $S_{\mathrm{s}}$ the stopping power of the sample, $S_{\mathrm{st}}$ stopping power of the standard, $\mathrm{Y}_{\mathrm{s}}$ the yield of the sample, and $Y_{\text {st }}$ the yield of the standard, in the following equation we determined the concentration of each element.

$$
\mathbf{C}_{\mathbf{s}}=\mathrm{C}_{\mathrm{st}} \frac{S_{s} Y_{s}}{S_{s t} Y_{s t}}
$$

Where

$\mathbf{C}_{\mathbf{s}}$ is the concentration of an element present in a sample.

The detection limit, which is a measure of sensitivity, is defined as the minimum amount of an element that gives a number of counts equal to three times the standard deviation of the background in a spectrum obtained from a target of, ideally, a pure element (Currte, 1968; Debertin and Helmer, 1988).

The sensitivity or the minimum detection limit (MDL) depends on the detector geometry and efficiency and other experimental factors including the possible effects of interfering reactions.

In a thick target this value expresses the interference free detection limit of the element, because in an ideal matrix containing no other elements, the spectrum obtained from the element under investigation will replicate the shape of the spectrum obtained from the pure element. 
Mathematically, the minimum detection limit is defined as;

Where,

$$
\mathrm{MDL}=3 \frac{\sqrt{N_{b}}}{S}
$$

$\mathrm{N}_{\mathrm{b}}=$ Number of counts $/ \mu \mathrm{C}$, in the background within an energy interval of two FWHM around the gamma-peak.

$\mathrm{S}=$ the sensitivity of the element.

\section{Results and Discussion}

The research work presented here has been done using a proton beam of energy $2.3 \mathrm{MeV}$ and current range of 10-20 nA. IAEA-407 was used as a reference material (Table-2). Table-3 shows a wide variation in the elemental concentrations of the different fish samples compared_with WHO Standard value.

Table-2: Concentration (in ppm) of reference material IAEA-407 and observed values (Dry weight basis) (Wyse et al., 2003).

\begin{tabular}{|c|c|c|c|c|}
\hline \multirow{2}{*}{ Element } & \multicolumn{2}{|c|}{ IAEA Values } & \multicolumn{2}{c|}{ Observed Values } \\
\cline { 2 - 5 } & Conc $(\mathrm{mg} / \mathrm{kg})$ & Unc $(\mathrm{mg} / \mathrm{kg})$ & Conc $(\mathrm{mg} / \mathrm{kg})$ & Unc $(\mathrm{mg} / \mathrm{kg})$ \\
\hline $\mathrm{Al}$ & 13.8 & 3.7 & 5.03 & 3.66 \\
\hline $\mathrm{As}$ & 12.6 & 1.2 & $\mathrm{ND}$ & $\mathrm{ND}$ \\
\hline $\mathrm{Br}$ & 94 & 9 & 65.12 & 3.21 \\
\hline $\mathrm{Ca}$ & 27000 & 1800 & 219.8 & 73.72 \\
\hline $\mathrm{Co}$ & 0.1 & 0.02 & $\mathrm{ND}$ & $\mathrm{ND}$ \\
\hline $\mathrm{Cr}$ & 0.73 & 0.22 & 4.29 & 1.12 \\
\hline $\mathrm{Cu}$ & 3.28 & 0.4 & 3.42 & 0.65 \\
\hline $\mathrm{Fe}$ & 146 & 14 & 163.51 & 24.89 \\
\hline $\mathrm{Hg}$ & 0.222 & 0.024 & $\mathrm{ND}$ & $\mathrm{ND}$ \\
\hline $\mathrm{K}$ & 13100 & 1200 & 52.66 & 6.44 \\
\hline $\mathrm{Mg}$ & 2720 & 140 & 12.4 & 1.46 \\
\hline $\mathrm{Mn}$ & 3.52 & 0.32 & 4.16 & 0.05 \\
\hline $\mathrm{Na}$ & 13100 & 600 & 13.2 & 2.96 \\
\hline $\mathrm{Rb}$ & 2.86 & 0.4 & 6.80 & 2.19 \\
\hline $\mathrm{Sb}$ & 0.011 & 0.002 & $\mathrm{ND}$ & $\mathrm{ND}$ \\
\hline $\mathrm{Se}$ & 2.83 & 0.38 & 5.40 & 1.98 \\
\hline $\mathrm{Sn}$ & 0.097 & 0.051 & $\mathrm{ND}$ & $\mathrm{ND}$ \\
\hline $\mathrm{Sr}$ & 130 & 11 & 85.11 & 5.28 \\
\hline $\mathrm{V}$ & 1.43 & 0.2 & 0.57 & 0.43 \\
\hline $\mathrm{Zn}$ & 67.1 & 3.8 & 57.94 & 0.65 \\
\hline & $\mathrm{Note}$ ND - Not Detected, & Unc & uncertainty & \\
\hline & & & & \\
\hline & & & & \\
\hline & & & & \\
\hline
\end{tabular}

Several trace elements are important as micronutrient to the human body and are required for the well-being of body's immune system. The 18 elements that were found in this work in fish samples are: Iron, Calcium, 
Sodium, Magnesium, Aluminum, Potassium, Vanadium, Chromium, Manganese, Copper, Zinc, Selenium, Bromine, Rubidium, Strontium, Cadmium, Iodine and Lead. All 18 elements were measured in all fish samples except Vanadium which was not detected in Rui and Taki.

\section{Calcium}

Calcium was found in all fish samples and varied with a wide range of $312.21-110.21 \mathrm{ppm}$. The highest concentration of Calcium was obtained in Mastacembelus armatus (312.21 ppm) and the lowest was measured in Anabas testudineus (110.21 ppm). Calcium, the most abundant mineral in the body, is usually required for vascular contraction and vasodilation, muscle function, nerve transmission, intracellular signaling and hormonal secretion (Committee to Review Dietary Reference Intakes for Vitamin D and Calcium, 2010).

\section{Potassium}

Anabas testudineus contained the highest amount of potassium (60.3 $\mathrm{ppm}$ ) and lowest amount of $\mathrm{K}$ was found in Mastacembelus armatus (45.3 $\mathrm{ppm})$. The elemental concentrations of potassium in Pangasius pangasius, Labeo rohita, Channa punctate, Oreochromis mossambicus were 45.35 ppm, $58.30 \mathrm{ppm}, 58.37 \mathrm{ppm}$, and $48.38 \mathrm{ppm}$, respectively. Potassium is an important positive ion in intracellular fluid. When the kidneys function poorly, potassium builds up in the blood, creating a condition called hyperkalemia (Whelton et al., 1997). 
Table-3: Elemental concentrations (in ppm) of the analyzed fish samples (on dry weight basis).

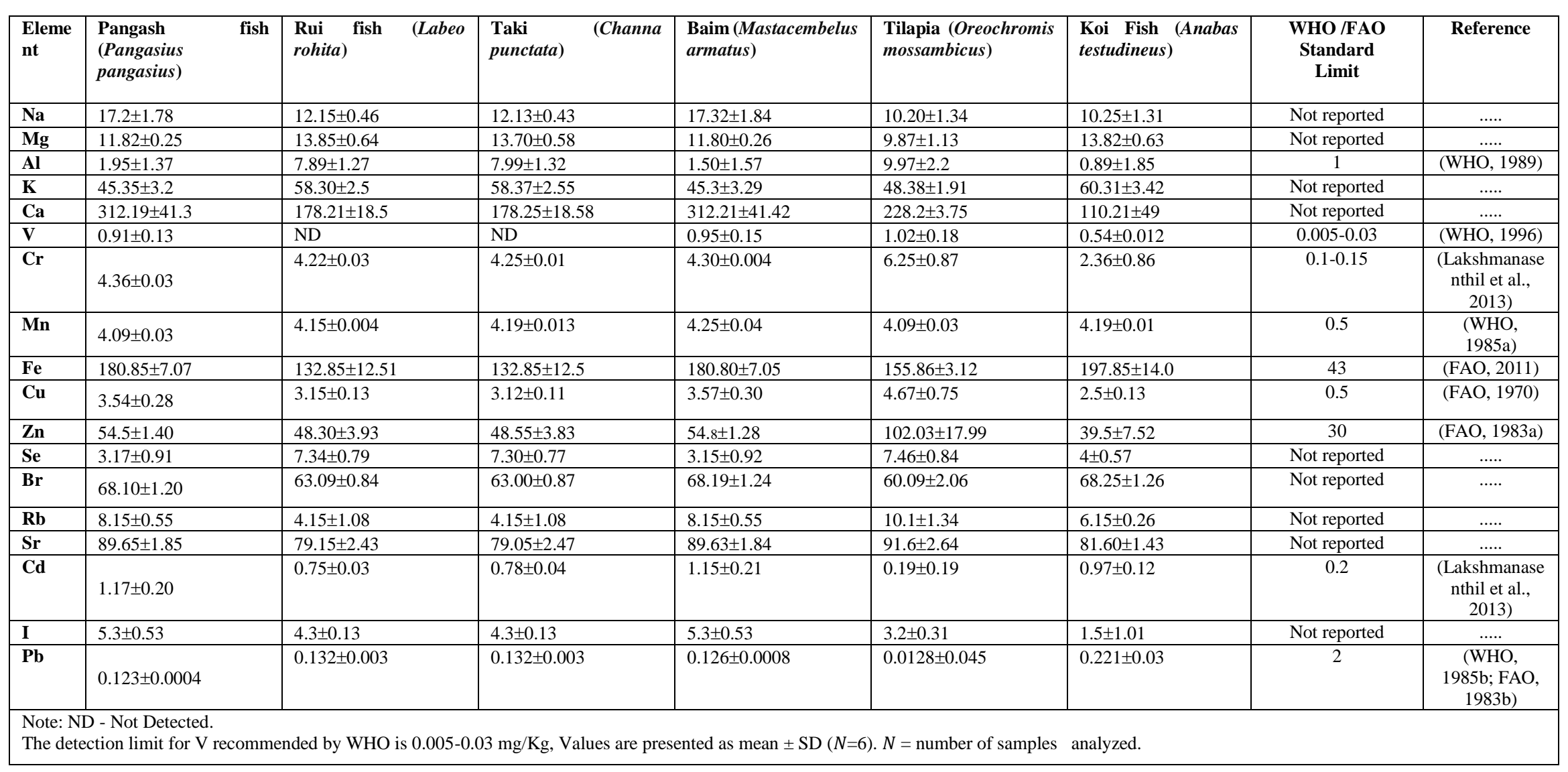




\section{Sodium}

Sodium was detected in all fish samples. Mastacembelus armatus contained the highest amount of $\mathrm{Na}(17.32 \mathrm{ppm})$ and lowest amount of $\mathrm{Na}$ was measured in Oreochromis mossambicus (10.20 ppm). Sodium is very important for the human body and plays an important role in conducting nerve impulses. It's the major electrolyte in extra cellular fluid. It was found that almost all fish samples contained sodium in considerable quantity.

\section{Magnesium}

$\mathrm{Mg}$ was measured in all six fish samples and ranged from 13.85 to 9.87 $\mathrm{ppm}$. The highest amount of $\mathrm{Mg}(13.85 \mathrm{ppm})$ was measured in Labeo rohita and on the other hand the lowest concentration was observed in Oreochromis mossambicus (9.87 ppm). Magnesium is a cofactor in more than 300 enzyme systems that regulate diverse biochemical reactions in the body, including protein synthesis, muscle and nerve function, blood glucose control, and blood pressure regulation (Institute of Medicine, 1997; Rude, 2010; Rude, 2012).

\section{Aluminum}

From this study it was observed that Al was detected in all fish samples. The amount of $\mathrm{Al}$ was in the range of 9.97-0.89 ppm. Al concentration was considerably higher in Oreochromis mossambicus $(9.97$ $\mathrm{ppm}$ ) than the other five samples. The maximum permissible limit of $\mathrm{Al}$ is 1 $\mathrm{mg} / \mathrm{Kg}$ according to FAO/WHO (World Health Organization, 1989). Al showed higher levels than the FAO/WHO limit in 5 fish samples while in Koi Fish (Anabas Testudineus) marginal levels were measured. According to the results of this study only Koi Fish (Anabas Testudineus) had marginal levels of $\mathrm{Al}$ whereas the other 5 fish samples exceeded the $\mathrm{FAO} / \mathrm{WHO}$ permissible limits. Therefore these 5 fish should be avoided. Al is the third most abundant element (after oxygen and silicon) in the Earth's environment. Despite its prevalence in the environment, no known form of life uses aluminum salts metabolically. In keeping with its pervasiveness, aluminum is well tolerated by plants and animals (Frank, 2009). Owing to their prevalence, the potential beneficial biological roles of aluminum compounds are of continuing interest.

\section{Iron}

The presence of Iron was observed in all the studied samples. The highest Fe content was found in Anabas testudineus (197.85 ppm) and the lowest concentration of $132.85 \mathrm{ppm}$ was found in Labeo rohita and Channa punctate. The Fe Concentration in all fish species studied were above the WHO/FAO maximum permissible limit of $43 \mathrm{mg} / \mathrm{kg}$ (FAO/WHO, 2011). Thus the local people are at high risk of excessive dietary Fe. 


\section{Manganese}

Within the studied samples, the highest concentration of $\mathrm{Mn}$ was measured in Mastacembelus armatus (4.25 ppm) followed by Anabas testudineus (4.19 ppm), Channa punctata (4.19 ppm), Labeo rohita (4.15 ppm), Oreochromis mossambicus (4.09 ppm), and Pangasius pangasius (4.09 $\mathrm{ppm})$. The concentration of Mn was found to be relatively high as compared with data reported for the standard IAEA-407. Mn levels in the examined fish samples of the current study were higher than the recommendation of WHO $(0.5 \mathrm{mg} / \mathrm{Kg})$ (World Health Organization, 1985a). Thus people of these areas are at high risk of excessive dietary $\mathrm{Mn}$.

\section{Zinc}

$\mathrm{Zn}$ is an indispensable or essential element for animals and almost 300 mammalian enzymes are related to $\mathrm{Zn}$ (Ross et al., 2014). The results indicate that all fish samples contain $\mathrm{Zn}$. The amount of $\mathrm{Zn}$ was in the range of 102.03$39.5 \mathrm{ppm}$. Oreochromis mossambicus had the highest $\mathrm{Zn}$ concentration (102.03 ppm) and the lowest concentration (39.5 ppm) was in Anabas testudineus. Pangasius pangasius, Labeo rohita, Channa punctate, Mastacembelus armatus showed Zn concentration of about 54.5 ppm, 48.30 ppm, $48.55 \mathrm{ppm}, 54.8 \mathrm{ppm}$ respectively. $\mathrm{Zn}$ is involved in numerous aspects of cellular metabolism. It is required for the catalytic activity of approximately 100 enzymes and it plays a role in immune function protein synthesis, wound healing, DNA synthesis, and cell division (Institute of Medicine, 2001; Prasad, 1995). Zn also supports normal growth and development during pregnancy, childhood, and adolescence and is required for proper sense of taste and smell (Prasad et al., 1997). The concentrations of $\mathrm{Zn}$ in all fish species were found to be above the FAO maximum permissible limit of $30 \mathrm{mg} / \mathrm{kg}$ (FAO, 1983a). Therfore people of this area are at a high risk of excessive dietary $\mathrm{Zn}$.

\section{Copper}

Micro mineral $\mathrm{Cu}$ was found in all fish samples analyzed. The highest $\mathrm{Cu}$ content was obtained in Oreochromis mossambicus (4.67 ppm) and the lowest $\mathrm{Cu}$ content was in Anabas testudineus (2.5 ppm). A lack of $\mathrm{Cu}$ may lead to increased blood fat levels. $\mathrm{Cu}$ is necessary for the manufacture of the neurotransmitter noradrenalin as well as for the pigmentation of hair (Bertrand, 1912). The $\mathrm{Cu}$ level in all fish samples were obtained far above the WHO/FAO maximum permissible limit of $0.5 \mathrm{mg} / \mathrm{kg}$ (FAO/WHO, 1970). Thus people of this area are at a high risk of excessive dietary $\mathrm{Cu}$.

\section{Selenium}

Se was found in all fish samples at variable concentrations. Oreochromis Mossambicus had the highest amount of Se (7.465 ppm) and the 
lowest was in Mastacembelus armatus (3.15 ppm). One of the main activities of this element is its anti-aging property and its ability to help rid the body of free radicals, as well as toxic minerals such as mercury, lead and cadmium. It is helpful in fighting infections since it stimulates increased antibody response to infections and promotes more energy in the body (Burk, 1976).

\section{Chromium}

$\mathrm{Cr}$ was detected in all of the samples investigated. The highest concentration of $\mathrm{Cr}$ was found in Oreochromis mossambicus $(6.25 \mathrm{ppm})$ and the lowest concentration was found in Anabas testudineus (2.36 ppm). Chromium is an essential nutrient required for normal sugar and fat metabolism and works primarily by the action of insulin. The concentration of chromium was relatively high as compared to the standard IAEA-407. High concentrations of chromium in the cell can lead to DNA damage (David et al., 2008). From the present study the $\mathrm{Cr}$ levels in fish samples were higher than the recommended limits proposed by WHO $(0.1-0.15 \mathrm{mg} / \mathrm{Kg})$ (Lakshmanasenthil et al., 2013). Due to the high amounts of $\mathrm{Cr}$ measured in fish samples consumption of these fish species should be avoided. Further work is required to determine whether this $\mathrm{Cr}$ exists as $\mathrm{Cr}$ (III) or $\mathrm{Cr}$ (VI).

\section{Vanadium}

$\mathrm{V}$ was found in all fish samples except Labeo rohita and Channa punctate. Oreochromis mossambicus had the highest amount of V which was 1.02 ppm and Anabas testudineus contained the lowest concentration (0.91 ppm). All V compounds should be considered toxic. Elemental concentrations of $\mathrm{V}$ in all fish samples were above the WHO recommended value except Laeo rohita and Channa punctate. The permissible range for $\mathrm{V}$ is $0.005-0.03$ $\mathrm{mg} / \mathrm{Kg}$, recommended by WHO (World Health Organization, 1996). Thus in this area consumption of local fish should be avoided due to excessive dietary $\mathrm{V}$ available in these fish samples.

\section{Bromine}

The concentration of Br differed markedly among the studied samples. The highest $\mathrm{Br}$ content (68.25ppm) was found in Anabas testudineus and the lowest value (60.09 ppm) was in Oreochromis mossambicus. The concentrations of $\mathrm{Br}$ found in Pangasius pangasius, Labeo rohita, Channa punctate, Mastacembelus armatus were 68.10 ppm, 63.09 ppm, 63.00 ppm, and $68.19 \mathrm{ppm}$ respectively. The Br concentrations were high as compared to those reported in the standard IAEA-407. Humans can absorb organic $\mathrm{Br}$ through skin, from food and during breathing. The most important health effects that can be caused by Br-containing organic contaminants are 
malfunctioning of the nervous system and disturbances in genetic materials (http://www.lenntech.com/periodic/elements/br.htm\#ixzz40WfYufjW).

\section{Rubidium}

$\mathrm{Rb}$ was found in all 6 fish samples studied. The highest concentration was $10.1 \mathrm{ppm}$ in Oreochromis mossambicus and the lowest value (4.15 ppm) was determined in Channa punctate and Labeo rohita. $\mathrm{Rb}$ is normally observed in animal tissue and it is similar to potassium in its delivery and excretory pattern (Hays and Swenson, 1985).

\section{Strontium}

The elemental concentration of $\mathrm{Sr}$ in Oreochromis mossambicus was $91.6 \mathrm{ppm}$, which was the highest amount of Sr among the various fish samples studied. The lowest amount of Sr was in Channa punctata $(79.05 \mathrm{ppm})$. The elemental concentrations of $\mathrm{Sr}$ in Pangasius pangasius, Labeo rohita, Mastacembelus armatus, Anabas testudineus were 89.65 ppm, 79.15 ppm, $89.63 \mathrm{ppm}, 81.60 \mathrm{ppm}$, respectively. The human body absorbs $\mathrm{Sr}$ as if it were calcium. Due to the chemical similarity of these elements, stable forms of Sr may not pose a significant health threat in fact, the levels found naturally may actually be beneficial but radioactive ${ }^{90} \mathrm{Sr}$ can lead to various bone disorders and diseases, including bone cancer.

\section{Cadmium}

Within the selected fish samples, the highest concentration of $\mathrm{Cd}$ was measured in Pangasius pangasius (1.17 ppm) followed by Mastacembelus armatus (1.15 ppm), Anabas testudineus (0.97 ppm), Channa punctata (0.78 ppm), Labeo rohita (0.75 ppm) and Oreochromis mossambicus (0.19 ppm). Foodstuff that are rich in $\mathrm{Cd}$ can greatly increase the $\mathrm{Cd}$ concentration in human bodies. $\mathrm{Cd}$ is first transported to the liver through the blood. There it bonds to proteins to form complexes that are transported to the kidneys. $\mathrm{Cd}$ accumulates in kidneys, where it damages the filtering mechanism. The maximum permissible limit of $\mathrm{Cd}$ concentration in the human body is 0.2 $\mathrm{mg} / \mathrm{Kg}$ (Lakshmanasenthil et al., 2013) as proposed by the WHO. According to the results of this study the concentration of $\mathrm{Cd}$ in Tilapia (Oreochromis mossambicus) was found within permissible level which do not cause any risk of excessive dietary $\mathrm{Cd}$ to the local population.

\section{Iodine}

According to the measured concentrations of iodine in fish samples it was observed that Pangasius pangasius and Mastacembelus armatus contained the highest amounts of I $(5.3 \mathrm{ppm})$ and lowest amount of I was in 
Anabas testudineus (1.5 ppm). I is a building material of thyroid hormones that are essential for growth, the nervous system and the metabolism.

\section{Lead}

$\mathrm{Pb}$ was detected in all six fish samples. The highest amount of $\mathrm{Pb}$ was found in Anabas testudineus (0.2214 ppm) and the lowest concentration was found in Oreochromis mossambicus $(0.0128 \mathrm{ppm}) . \mathrm{Pb}$ is a highly poisonous metal (whether inhaled or swallowed), affecting almost every organ and system in the body. The main target for $\mathrm{Pb}$ toxicity is the nervous system, both in adults and children. Long-term exposure of adults can result in decreased performance in some tests that measure functions of the nervous system ("Lead in Air", Britannica Online Encyclopedia). The mean concentrations of $\mathrm{Pb}$ detected in the fish samples from this study was below the WHO/FAO maximum permissible limit of $2 \mathrm{mg} / \mathrm{kg}$ (World Health Organization, 1985b; FAO, 1983b). In the analyzed fish samples there are no health risks due to $\mathrm{Pb}$ to the local population.

The studied elements accumulate in vital organs in the human body such as the kidneys, bones, and liver which excessive dietary may result in numerous serious health effects such as neurotoxic and carcinogenic effects. Among the studied elements, $\mathrm{Cr}$ is known to cause various pulmonary disorders, while high intake of $\mathrm{Cu}$ can cause liver and kidney damage. $\mathrm{Cd}$ is toxic to the cardiovascular system, kidneys, and bones. Excessive intake of $\mathrm{Zn}$ can cause negative effects on immunological system and cholesterol metabolism. Excess intake of Mn can result in psychological and neurologic disorder (Ahmed et al., 2016). An investigation on excessive dietary effect of $\mathrm{Fe}, \mathrm{Mn}, \mathrm{Zn}, \mathrm{Cu}, \mathrm{Cr}, \mathrm{V}$, I etc. with the members of five local families was carried out and the health effects like liver or kidney damage and psychological disorder were observed with few of them. A detail study and further work on local population health is required to determine the exact excessive dietary effect of the studied elements.

\section{Conclusion}

Elemental concentrations of six fish samples, which are regularly consumed by the local population were determined using PIGE technique. The accuracy and precision of the technique were assured by analyzing Standard Reference materials. $\mathrm{Na}, \mathrm{Mg}, \mathrm{Al}, \mathrm{K}, \mathrm{Ca}, \mathrm{V}, \mathrm{Cr}, \mathrm{Mn}, \mathrm{Fe}, \mathrm{Cu}, \mathrm{Zn}, \mathrm{Se}, \mathrm{Br}, \mathrm{Rb}$, $\mathrm{Cd}, \mathrm{Sr}$, I and $\mathrm{Pb}$ were determined in the studied fish samples. All the studied fish species were found to contain good amount of trace elements like $\mathrm{Fe}, \mathrm{Cu}$, $\mathrm{Zn}$, Mn etc. which have immunomodulatory functions in the human system. It was found that the elemental concentrations of $\mathrm{Mn}$ and $\mathrm{Cr}$ were higher in fish samples studied than in the standard sample IAEA-407 which may cause health hazard to the human body. According to the WHO/FAO standard limit 
the studied elemental concentrations of $\mathrm{Fe}, \mathrm{Mn}, \mathrm{Zn}, \mathrm{Cu}, \mathrm{Cr}$ and $\mathrm{V}$ in the fish samples were found above the limiting value. Thus the local peoples are at high risk of excessive Dietary $\mathrm{Fe}, \mathrm{Mn}, \mathrm{Zn}, \mathrm{Cu}, \mathrm{Cr}, \mathrm{V}$ and I. This work presents a preliminary study to make a baseline data in this area. Further work is required to study the effects on humans from consumption of such food articles.

\section{Acknowledgements}

The authors are very thankful to Dr. Md. Joynal Abedin, Principal Scientific Officer, Van de Graff Accelerator Division, Atomic Energy Centre Dhaka, Bangladesh. The authors are also thankful to the operational staff of the Van de Graff Accelerator Division, Atomic Energy Centre Dhaka, Bangladesh for their cooperation during the experimental works.

\section{References:}

1. Ahmed M. K., Baki M. A., Kundu G. K., Islam M. S., Islam M. M. and Hossain M. M., (2016). Human health risks from heavy metals in fish of Buriganga river, Bangladesh. Springer Plus (2016) 5:1697. DOI 10.1186/s40064-016-3357-0

2. Allaway W. H., (1965). The trace elements in biological systems, In trace analysis, Physical methods, G. H. Morison (ed), Interscience publishers, John Wiley \& sons, Inc, New York, 1965.

3. Bertrand C., (1912). Proc. Int. Congr. Appl. Chem., 28. (1912)28.

4. Burk R. F., (1976). Selenium in man. In: Trace elements in human health and disease, Vol. II. (A. S. Prasad, Ed.) Academic Press, New York, 1976, pp. 105-133.

5. Burton J. A., Hull G. W., Morin F. J. and Severeins J. C., (1953). "Effect of Nickel and Copper Impurities on the Recombination of Holes and Electrons in Germanium", Journal of Chemical Physics, vol. 57, pp. 853, 1953.

6. Committee to Review Dietary Reference Intakes for Vitamin D and Calcium, (2010). Food and Nutrition Board, Institute of Medicine. Dietary Reference Intakes for Calcium and Vitamin D. Washington, DC: National Academy Press, 2010.

7. Currte L. A., (1968). Anal. Chem., 40 (1968)586.

8. David Eastmond A., Mac Gregor J. T., Slesinski R. S., (2008). "Trivalent Chromium: Assessing the Genotoxic Risk of an Essential Trace Element and Widely Used Human and Animal Nutritional Supplement". Critical Reviews in Toxicology. 38 (3):173-190. doi:10.1080/10408440701845401. PMID 18324515.

9. Debertin K. and Helmer R. G., (1988). Gamma and X-ray spectrometry with semiconductors, North Holand, Amsterdam,1988. 
10. Deconninck G., (1978). Radioanalytical Amsterdam, Introduction to Physics, Elsevier.

11. FAO/WHO, (2011). Joint FAO/WHO food standards programme codex committee on contaminants in foods, fifth. session, pp 64-89.

12. FAO/WHO, (1970). Expert Committee on Food Additives: Toxicological Evaluation of Some Extraction Solvents and Certain Other Substances.14th Meeting of the Joint FAO/WHO. Ser.48A. World Health Organization, Geneva.

13. FAO, (1983a). Compilation of legal limits for hazardous substances in fish and fishery products. FAO Fishery Circular No. 764, FAO. Rome, Italy, pp: 1-102.

14. FAO, (1983b). Compilation of legal limits for hazardous substances in fish and fishery products. FAO Fishery Circular, No. 464, pp:5-100.

15. Fazlul Hoque A. K. M., (2000). Analytical Application of Charged Particle Induced Nuclear Reactions for Low Mass Elemental Analysis, PhD Dissertation, Physics Department, Jahangirnagar University, (2000).

16. Fazlul Hoque A. K. M., Khaliquzzaman M., Hossain M. D. and Khan A. H., (2002a). Determination of fluoride in water residues by proton induced gamma emission measurements, 35(3), 1 (2002).

17. Fazlul Hoque A. K. M., Khaliquzzaman M., Hossain M. D. and Khan A. H., (2002b). Fluoride levels in different drinking water sources in bangladesh, 36(1), 38 (2002).

18. Frank W. B., (2009). "Aluminum". Ullmann's Encyclopedia of Industrial Chemistry. Wiley-VCH. doi:10.1002/14356007.a01_459.pub2

19. Hays W. and Swenson M. J., (1985). “ Minerals a n d bones ," i n Dukes 'Physiology of Domestic Animals, M. J. Swenson ,Ed., Cornell University Press, New York, NY, USA, 10th edition, 1985.

20. http://www.lenntech.com/periodic/elements/br.htm\#ixzz40WfYufjW

21. Institute of Medicine (IOM), (1997). Food and Nutrition Board. Dietary Reference Intakes: Calcium, Phosphorus, Magnesium, Vitamin D and Fluorideexternal link disclaimer. Washington, DC: National Academy Press, 1997.

22. Institute of Medicine, (2001). Food and Nutrition Board. Dietary Reference Intakes for Vitamin A, Vitamin K, Arsenic, Boron, Chromium, Copper, Iodine, Iron, Manganese, Molybdenum, Nickel, Silicon, Vanadium, and Zinc. Washington, DC: National Academy Press, 2001.

23. Lakshmanasenthil S., Vinothkumar T., AjithKumar T. T., Marudhupandi T., Veettil D. K., Ganeshamurthy R., Ghosh S. and Balasubramanian T., (2013). "Harmful metals concentration in 
sediments and fishes of biologically important estuary, Bay of Bengal", Journal of Environmental Health Sciences \& Engineering 2013, 11:33. http://www.ijehse.com/content/11/1/33.

24. "Lead in Air". Britannica Online Encyclopedia.

25. Ministry of agriculture fisheries and food, (1978); Summery of regulations and recommendations for heavy metals or United Kingdom, Food contamination branch (MAFF, London, 1978).

26. National research council committee on food protection, (1972). Food, Chemical Codex, 2nd edn. ix-xii (NAS, Washington, 1972).

27. Prasad A. S., (1995). Zinc: an overview. Nutrition 1995; 11:93-9. [PubMed abstract]

28. Prasad A. S., Beck F. W., Grabowski S. M., Kaplan J., Mathog R. H., (1997). Zinc deficiency: changes in cytokine production and T-cell subpopulations in patients with head and neck cancer and in noncancer subjects. Proc Assoc Am Physicians 1997; 109:68-77. [PubMed abstract]

29. Ross A.C., Caballero B., Cousins R.J., Tucker K.L., and Ziegler T.R., (2014). Modern Nutrition in Health and Disease, Lippincott Williams \& Wilkins, Philadelphia, Pa, USA, 11th edition, 2014.

30. Rude R. K., (2010). Magnesium. In: P. M. Coates, J. M. Betz, M. R. Blackman, G. M. Cragg, M. Levine, J. Moss, J. D. White, eds. Encyclopedia of Dietary Supplements. 2nd ed. New York, NY: Informa Healthcare; 2010:527-37.

31. Rude R. K., (2012). Magnesium. In: A. C. Ross, B. Caballero, R. J. Cousins, K. L. Tucker, T. R. Ziegler, eds. Modern Nutrition in Health and Disease. 11th ed. Baltimore, Mass: Lippincott Williams \& Wilkins; 2012:159-75.

32. Tesmer J. R. and Nastasi M. (eds.) (1995). Handbook of Modern lon Beam Materials Analysis, Materials Research Society, Pittsburgh, Pennsylvania, (1995).

33. Underwood E. J., (1977). Trace elements in human and animal nutrition, 4th edition, Academic press, New York, 1977.

34. Water quality Criteria, (1972). National academy of science and engineering, Washington, 1972.

35. Whelton P. K., He J., Cutler J. A., Brancati F. L., Appel L. J., Follmann D., Klag M. J. (1997)."Effects of oral potassium on blood pressure. Meta-analysis of randomized controlled clinical trials". JAMA 277 (20): 1624-32. doi:10.1001/jama.1997.03540440058033. PMID 9168293.

36. World Health Organization, Geneva, (1989). Evaluation of certain food additives and contaminants. Thirty-third Report of the Joint 
FAO/WHO Expert Committee on Food Additives. (WHO Technical Report Series, No. 776).

37. World Health Organization, Geneva, (1996). Trace elements in human nutrition and health, page- 182 .

38. World Health Organization, (1985a). Guidelines for the study of dietary intakes of chemical contaminants. World Health Organization, Geneva.

39. World Health Organization, (1985b). Guidelines for Drinking Water Quality (ii): Health Criteria and Supporting Information. Vol. 1, Recommendations. WHO, Geneva. 130pp.

40. Wyse E. J., Azemard S. and de Mora S. J., (2003). Report on the worldwide intercomparison exercise for the determination of trace elements and methylmercury in fish homogenate IAEA-407. IAEA/AL/144, IAEA/MEL/72, IAEA, pp. 94. 